\title{
PENGEMBANGAN MODEL PEMBELAJARAN MATEMATIKA BERBASIS BUDAYA MELALUI PERMAINAN TRADISIONAL JAWA
}

\author{
Riani Ika Oktafianti ${ }^{1}$, Riawan Yudi Purwoko ${ }^{2}$, Erni Puji Astuti ${ }^{3}$ \\ rianiika107@gmail.com, riawanyudi@umpwr.ac.id, ernipuji@umpwr.com \\ 1,2,3 Universitas Muhammadiyah Purworejo
}

\begin{abstract}
The purpose of this study was to develop a culture-based mathematics learning model through traditional Javanese games and find out the feasibility so that it could be used for elementary school students. This development research uses the ADDIE model (Analysis, Design, Development, Implementation, and Evaluation). Through these stages of development, it produce culture-based mathematics learning model through traditional Javanese games products with the main products in the form of model books, student books, teacher books, syllabus, lesson plans, and student worksheets. The research subjects were 19 fourth grade students at Klegenwonosari Elementary School. The data collection techniques in this study were carried out test and non-test. The data analysis technique in this study was in scores and percentages. Starting from the needs analysis of learning models, culture-based needs analysis, and curriculum analysis it is known that the use of mathematical learning models through traditional games has been done but outside learning, students were lack of knowledge about the traditional Javanese culture games that were Gobag Sodor and Engklek. Based on the results of the study, the mathematical learning model through traditional Javanese games fulfills the valid criteria with an average score of 3.79 from the model expert's assessment. Fulfill the effective criteria by obtaining the results of completeness of students $84.21 \%$ and get very positive students responses with a percentage of $90.90 \%$. Therefore, Culturebased Mathmatics learning model through traditional Javanese games is suitable for elementary students.
\end{abstract}

Keywords: traditional Javanes games, mathematics models, ethnomatematics

\section{Abstrak}

Tujuan penelitian ini adalah mengembangkan model pembelajaran matematikaberbasis budaya melalui permainan tradisional Jawa dan mengetahui kelayakan sehingga dapat digunakan untuk siswa Sekolah Dasar. Penelitian pengembangan ini menggunakan model ADDIE (Analysis, Design, Development, Implementation, and Evaluation). Dimulai dari analisis kebutuhan model pembelajaran, analisis kebutuhan berbasis budaya, dan analisis kurikulum diketahui bahwa penggunaan model pembelajaran matematika melalui permainan tradisional pernah dilakukan namun diluar pembelajaran, kurang wawasan siswa mengetahui budaya permainan tradisional Jawa Gobag Sodor dan Engklek. Berdasarkan hasil penelitian, model pembelajaran matematika melalui permainan tradisional Jawa memenuhi kriteria valid dengan rata-rata skor 3,79 dari penilaian ahli model. 
Memenuhi kriteria praktis dengan rata-rata skor 3,80. Memenuhi kriteria efektif dengan diperoleh hasil ketuntasan siswa $84,21 \%$ dan mendapatkan respon siswa yang sangat positif dengan presentase $90,90 \%$. Sehingga model pembelajaran matematika berbasis budaya melalui permainan tradisional Jawa layak digunakan untuk siswa SD.

Kata kunci: permainan tradisional jawa, model matematika, etnomatematika

\section{ARTICLE HISTORY:}

Received: 2019-08-23, Revised: 2019-08-24,

Accepted: 2019-09-01, Onlinefirst: 2019-09-07

\section{PENDAHULUAN}

Indonesia merupakan Negara Kepulauan dengan keanekaragaman budaya yang berbeda-beda. Keanekaragaman budaya tersebut pada setiap daerah memiliki karakteristik budaya tersendiri. Salah satu budayanya adalah permainan tradisional. Permainan tradisional ini memiliki ciri kedaerahan sesuai dengan tradisi dan budaya setempat, termasuk di pulau Jawa juga memiliki ciri pada budayanya. Dalam permainan tradisional dapat mengembangkan kecerdasan intelektual pada sesorang anak. Namun, perkembangan zaman yang semakin modern perlahan-lahan menggeser keberadan budaya termasuk permainan tradisional yang mulai tergantikan oleh game online. Dengan perkembangan tersebut generasi muda tidak mengenal permainan tradisional dan kurang menghargai budaya dan karakter. Untuk memperbaiki hal tersebut perlu penerapan budaya ke dalam pendidikan.

Pendidikan dapat dikaitkan dengan nilai-nilai budaya didalamnya. Etnomatematika hadir untuk menjembatani antara budaya dan pendidikan. Selain itu, ada hal yang penting dari pendidikan yaitu pembelajaran. Pembelajaran tidak terlepas dari sifat perkembangan intelektual peserta didik yang diajar. Melalui pembelajaran diharapkan dapat direncanakan dengan baik agar peserta didik dapat mengikuti dengan baik. Begitu juga dalam pembelajaran matematika. Matematika merupakan mata pelajaran yang wajib dipelajari di semua jenjang pendidikan. Dan matematika merupakan ilmu yang dapat diterapkan dalam kehidupan sehari-hari. Kesulitan siswa memahami materi matematika yang abstrak dan menganggap matematika sulit inilah yang mengharuskan guru untuk menentukan model pembelajaran yang tepat. Penelitian ini bertujuan untuk mengetahui bagaimana mengembangkan model pembelajaran matematika berbasis budaya melalui permainan tradisional Jawa dan mengetahui 
kelayakan dari pengembangan model pembelajaran matematika berbasis budaya melalui permainan tradisional Jawa.

\section{METODE PENELITIAN}

Penelitian ini merupakan penelitian pengembangan (Research and Development), yakni menggembangkan model pembelajaran matematika berbasis budaya melalui permainan tradisional. Waktu penelitian dilakukan pada bulan Oktober 2018 sampai Juli 2019. Tempat penelitian di SD Negeri Klegenwonosari. Subjek penelitian ini adalah siswa kelas IV SD Negeri Klegenwonosari dengan jumlah 19 siswa. Penelitian ini dalam pengembangan model pembelajaran dengan model pengembangan ADDIE Sugiyono (2008), berikut tahapan pengembangan: Tahap 1. Analysis. Kegiatan analisis yang dilakukan untuk memperoleh gambaran tentang analisis kebutuhan model pembelajaran, analisis kebutuhan berbasis budaya, dan analisis kebutuhan kurikulum. Kegiatan tahap ini antara lain: wawancara dengan guru untuk memperoleh informasi dan observasi. Tahap 2. Design. Tahap ini merupakan tahapan perancangan model pembelajaran matematika berbasis budaya melalui permainan tradisional Jawa. Kegiatan yang dilakukan merancang kegiatan pembelajaran dengan model pembelajaran yang dikembangkan. Tahap 3. Development. Tahap ini merupakan tahapan merealisasikan rancangan kegiatan pemeblajaran yang sudah dilakukan sebelumnya. Dalam tahap ini, kerangka yang masih konseptual tersebut direalisasikan menjadi produk yang siap diimplementasikan. Dengan kata lain, tahapan ini merupakan tahapan membuat produk yang telah direncanakan pada tahap desain. Tahap 4. Implementation. Tahap ini merupakan tahapan mengimplementasikan pada situasi yang nyata yaitu di kelas. Tahap 5. Evaluation. Dalam tahap ini melakukan evaluasi di akhir tatap muka. Jika hasil evaluasi belum sesuai, dilakukan revisi pada pengembangan selanjutnya untuk mengetahui kelayakan model pembelajaran tersebut. Teknik pengumpulan data pada penelitian ini menggunakan 2 metode, yaitu metode tes dan nontes. Untuk metode tes, data diambil dari tes prestasi belajar dari siswa sebelum dan sesudah perlakuan. Jenis data penelitian ini adalah data kualitatif dan data kuantitatif. Data kualitatif dianalisis berdasarkan dengan berdasarkan model Miles and Huberman dalam Sugiyono (2018). Data kuantitatif berasal dari hasil tes dan validasi produk oleh ahli kemudian dianalisis berdasarkan penjelasan pada kriteria kevalidan, kepraktisan, dan keefektifan sesuai 
dengan rumusan Khabibah dalam Wicaksono (2014).

\section{HASIL DAN PEMBAHASAN}

Penelitian ini merupakan penelitian pengembangan, model pengembangan yang digunakan pada penelitian ini terdiri dari 5 tahap pengembangan yang meliputi: Analisis, Design, Development, Implementationn, and Evaluation (ADDIE). Pada tahap Analisis mendapatkan data dari analisis kebutuhan model pembelajaran, analisis kebutuhan basis budaya dan analisis kebutuhan kurikulum. Dari hasil analisis tersebut mendapatkan informasi bahwa model pembelajaran matematika berbasis budaya melalui permainan tradisional Jawa memang perlu dikembangkan dan sesuai dengan kurikulum 2013 yang berlaku dalam sekolah SD Negeri Klegenwonosari. Tahap Desain, tahap merancang produk yang dikembangkan dengan memuat nilai-nilai budaya di dalam pembelajaran matematika, sehingga produk yang dikembangkan berbasis Etnomatematika. Tahap Development, tahap ini mengembangkan produk yang telah di desain. Produk yang dihasilkan yaitu buku model, buku siswa, buku guru, silabus, RPP, dan LKS. Selain itu, untuk kelengkapan lainnya seperti angket respon siswa, lembar keterlaksanaan, kepraktisan, keefektifan dan soal tes juga dikembangkan.

Produk yang dikembangkan divalidasi oleh validator yang sesuai dengan keahliannya. Pengembangan buku model pembelajaran yang telah divalidasi menghasilkan dalam kategori valid. Berikut hasil validasi:

Tabel 1. Hasil Validasi Buku Model Pembelajaran

\begin{tabular}{|c|c|c|}
\hline No & Aspek yang dinilai & $\begin{array}{c}\text { Skor rata-rata } \\
\text { aspek }\end{array}$ \\
\hline 1 & Kekuatan Teori Pendukung & 4,00 \\
\hline 2 & Kesederhanaan & 3,25 \\
\hline 3 & Teknis & 3,50 \\
\hline 4 & $\begin{array}{l}\text { Keterkaitan Antara Komponen-komponen } \\
\text { Model Pembelajaran }\end{array}$ & 4,00 \\
\hline 5 & Bahasa & 4,00 \\
\hline 6 & Budaya & 4,00 \\
\hline & Total rata-rata validitas & 3,79 \\
\hline
\end{tabular}

Produk selanjutnya buku bahan ajar yang dikembangkan dan telah divalidasi menghasilkan dalam kategori valid. Adapun hasil validasi sebagi berikut: 
Tabel 2. Hasil Validasi Buku Bahan Ajar

\begin{tabular}{clc}
\hline No & Aspek yang dinilai & Skor rata-rata aspek \\
\hline 1 & Aspek Tampilan & 3,75 \\
\hline 2 & Kesesuaian Isi & 3,75 \\
\hline 3 & Aspek Bahasa & 4,00 \\
\hline 4 & Aspek Budaya & 3,66 \\
\hline & Total rata-rata validitas & $\mathbf{3 , 7 9}$ \\
\hline
\end{tabular}

Silabus pembelajaran yang dikembangkan merupakan silabus untuk sekolah dasar kelas IV dan sesuai dengan Kurikulum 2013. Silabus yang dikembangkan divalidasi dan menghasilkan dalam kategori valid. Berikut hasil validasi silabus pembelajaran:

Tabel 3. Hasil Validasi Silabus Pembelajaran

\begin{tabular}{clc}
\hline No & \multicolumn{1}{c}{ Aspek yang dinilai } & $\begin{array}{c}\text { Skor rata- } \\
\text { rata aspek }\end{array}$ \\
\hline 1 & $\begin{array}{l}\text { Kesesuaian format silabus dengan BSNP (Badan } \\
\text { Standar Nasional Pendidikan) }\end{array}$ & 3,00 \\
\hline 2 & Kesesuaian KI dan KD yang diperlukan & 4,00 \\
\hline 3 & Kesesuaian indikator dengan KD & 4,00 \\
\hline 4 & $\begin{array}{l}\text { Ketercakupan aspek disiplin, jujur, toleransi, kerja } \\
\text { keras, tekun, dan tanggung jawab }\end{array}$ & 4,00 \\
\hline 5 & Kesesuaian pengalaman belajar dengan indikator & 3,00 \\
\hline 6 & Ketercakupan alokasi waktu dengan KI & 3,00 \\
\hline 7 & $\begin{array}{l}\text { Kesesuaian teknik penilaian dengan indikator } \\
\text { penilaian }\end{array}$ & 3,00 \\
\hline 8 & Kesesuaian sumber belajar dengan indikator & 3,00 \\
\hline 9 & $\begin{array}{l}\text { Kesesuaian penggunaan permainan tradisional } \\
\text { Jawa dalam silabus pembelajaran matematika }\end{array}$ & 4,00 \\
\hline 10 & $\begin{array}{l}\text { Ketepatan letak dan peran permainan tradisional } \\
\text { dalam silabus pembelajaran matematika }\end{array}$ & 4,00 \\
\hline \multicolumn{1}{c}{ Total rata-rata validitas } \\
\hline
\end{tabular}

Dalam pengembangan Rencana Pelaksanaan Pembelajaran (RPP) dirancang sebagai pedoman dan acuan dalam melaksanakan pembelajaran. RPP yang dikembangkan dan telah divalidasi oleh validator menghasilkan hasil dalam kategori valid. Berikut hasil validasi RPP yang dikembangkan: 
Tabel 4. Hasil Validasi Rencana Pelaksanaan Pembelajaran

\begin{tabular}{clc}
\hline No & \multicolumn{1}{c}{ Aspek yang dinilai } & Skor rata-rata aspek \\
\hline 1 & Identitas Mata Pelajaran & 3,50 \\
\hline 2 & Rumusan Tujuan/Indikator & 3,66 \\
\hline 3 & Materi & 3,00 \\
\hline 4 & Metode Pembelajaran & 3,66 \\
\hline 5 & Kegiatan Pembelajaran & 3,33 \\
6 & Penilaian Media/ Sumber Belajar & 3,33 \\
\hline 7 & Penilaian Hasil Pembelajaran & 3,66 \\
\hline 8 & Kebahasaan & 3,66 \\
\hline 9 & Pengembangan Karakter & 3,50 \\
\hline 10 & Peran Budaya & 3,50 \\
\hline \multicolumn{2}{c}{ Total rata-rata Validitas } & $\mathbf{3 , 4 8}$ \\
\hline
\end{tabular}

LKS dikembangkan sebagai pendukung pembelajaran. LKS disusun sesuai dengan RPP dan didesain agar mudah dipahami oleh siswa SD. LKS yang dikembangkan divalidasi oleh validator menghasilkan hasil dalam kategori valid. Adapun hasil validasinya adalah sebagai berikut:

Tabel 5. Hasil Validasi LKS

\begin{tabular}{clc}
\hline No & \multicolumn{1}{c}{ Aspek yang dinilai } & Skor rata-rata aspek \\
\hline 1 & Aspek Petunjuk & 3,60 \\
\hline 2 & Kesesuaian Isi & 3,25 \\
\hline 3 & Aspek Bahasa & 3,25 \\
\hline 4 & Aspek Budaya & 3.33 \\
\hline & Total rata-rata validitas & $\mathbf{3 , 3 6}$ \\
\hline
\end{tabular}

Pengembangan lembar keterlaksanaan dikembangkan sesuai dengan RPP. Lembar ini disesuaikan dengan kegiatan pembelajaran yang dirancang. Pengisian lembar keterlaksanaan diisi oleh guru sebagai observer dalam penerapan model yang dikembangkan. Pengembangan lembar kepraktisan juga disusun untuk mengetahui bagaimana pelaksanaan model pembelajaran yang dikembangkan. Lembar kepraktisan ini diisi oleh obeserver yaitu guru. Pengembangan lembar keefektifan disusun untuk mengetahui apakah model tersebut efektif. Lembar ini dikembangkan dari aspek isi, respon siswa, kemudahan pelaksanaan model dan manfaat. Selain dilihat dari lembar keefektifan, keefektifan model pembelajaran juga dilihat dari persentase ketuntasan hasil belajar siswa dan angket respon siswa. Pengembangan angket respon siswa juga dikembangkan. Angket respon siswa divalidasi oleh validator dan hasilnya dalam kategori valid. Berikut hasil validasinya: 
Tabel 6. Hasil validasi angket respon siswa

\begin{tabular}{clc}
\hline No & \multicolumn{1}{c}{ Aspek yang dinilai } & Skor rata-rata aspek \\
\hline 1 & Pembelajaran & 3,20 \\
\hline 2 & Kebudayaan & 3,75 \\
\hline 3 & Tampilan Bahan Ajar & 3,50 \\
\hline & Total rata-rata validitas & $\mathbf{3 , 4 8}$ \\
\hline
\end{tabular}

Soal tes evaluasi juga dikembangkan sebagai salah satu indikator keefektifan model pembelajaran. Tes evaluasi ini diujikan pada siswa kelas IV SD Negeri Klegenwonosari. Adapun bentuk soal evaluasi yang diujikan soal essay singkat dengan jumlah 10 soal. Soal tes yang dikembangkan telah divalidasi oleh validator dan hasilnya semua soal sesuai dengan kriteria dan dapat digunakan tanpa revisi.

Tahap Implementasi, produk yang telah dikembangkan diimplementasikan pada situasi yang nyata yaitu di kelas dengan menerapkan model pembelajaran matematika berbasis budaya melalui permainan tradisional Jawa. Implementasi model pembelajaran yang dikembangkan dilaksanakan sebanyak 1 kali pertemuan, dimana untuk menyampaikan materi dan melakukan evaluasi. Dalam tahap ini, peneliti juga dibantu oleh observer untuk melihat dan memberikan penilaian terhadap keterlaksanaan, kepraktisan, dan keefektifan model pembelajaran yang dikembangkan. Adapun hasil penilaian dari observer adalah sebagai berikut.

Tabel 7. Hasil Penelitian Keterlaksanaan

\begin{tabular}{clc}
\hline No & \multicolumn{1}{c}{ Kegiatan } & Skor rata-rata \\
\hline 1 & Pembukaan & 3,75 \\
\hline 2 & Inti & 3,54 \\
\hline 3 & Penutup & 3,50 \\
\hline \multicolumn{2}{c}{ Total rata-rata kegiatan } & $\mathbf{3 , 6 0}$
\end{tabular}

Hasil penelitian keterlaksanaan oleh observer dalam kategori sangat baik. Selain menilai keterlaksanaan, juga memberikan penilaian terhadap kepraktisan model. Nilai kepraktisan model pembelajaran matematika berbasis budaya melalui permainan tradisional Jawa dalam kategori baik. Berikut adalah hasil penilaian kepraktisan.

Tabel 8. Hasil Penilaian Kepraktisan

\begin{tabular}{clc}
\hline No & \multicolumn{1}{c}{ Aspek yang dinilai } & Skor rata-rata aspek \\
\hline 1 & Isi & 3,75 \\
\hline 2 & Fungsi & 3,87 \\
\hline 3 & Kemudahan & 3,60 \\
\hline 4 & Budaya & 4,00 \\
\hline \multicolumn{2}{c}{ Total rata-rata validitas } & $\mathbf{3 , 8 0}$ \\
\hline
\end{tabular}


Selain keterlaksanaan dan kepraktisan, observer juga menilai keefektifan model pembelajarannya. Adapun hasil dari penilaian tersebut adalah keefektifan model pembelajaran dala kategori baik. Berikut adalah hasil penilaiannya.

Tabel 9. Hasil Penilaian Keefektian

\begin{tabular}{clc}
\hline No & \multicolumn{1}{c}{ Aspek yang dinilai } & Skor rata-rata \\
\hline 1 & Fungsi & 3,80 \\
\hline 2 & Kemudahan & 3,60 \\
\hline 3 & Budaya & 4,00 \\
\hline \multicolumn{2}{c}{ Total rata-rata aspek } & $\mathbf{3 , 8 0}$ \\
\hline
\end{tabular}

Selain itu peneliti mengamati dan mencatat aktifitas pembelajaran yang terjadi selama tahap implementasi. Hasil pengamatan tersebut dihimpun dalam sebuah catatan lapangan. Dalam catatan lapangan menunjukkan siswa antusias, aktif dalam bertanya maupun memberi pendapat, dan senang dengan model pembelajaran matematika yang dilaksanakan. Pada akhir pembelajaran dilakukan evaluasi dan juga pengisian angket respon siswa. Hasil respon siswa menunjukkan kategori sangat positif dengan presentase 90,90\%. Dengan demikian dapat disimpulkan bahwa respon siswa terhadap model pembelajaran matematika melalui permainan tradisional jawa sangat baik. Tahap Evaluasi menggunakan rancangan tes sebagai salah satu indikator untuk mengetahui kelayakan produk pengembangan. Tes evaluasi terdiri dari 10 soal essay singkat tentang keliling dan luas daerah. Tes evaluasi ini diberikan kepada 19 subjek siswa kelas IV SD Klegenwonosari. Dari hasil evaluasi, hasil ketuntasan belajar siswa 84,21\% dari KKM 60.

Pengembangan model pembelajaran matematika berbasis budaya melalui permainan tradisional Jawa ini dilatarbelakangi oleh minimnya pengetahuan budaya permainan tradisional Jawa pada siswa dan kesulitan siswa SD dalam pembelajaran matematika yang abstrak. Pengembangan model pembelajaran ini bertujuan untuk mengetahui kelayakan produk model pembelajaran. Tahapan penelitian yang dilakukan sesuai dengan pernyataan Endang (2014) bahwa pengembangan produk penelitian ada lima tahap yaitu tahap analisis, desain, pengembangan, implementasi, dan evaluasi. Tahapan-tahapan yang dilakukan ini merupakan tahapan model pengembangan ADDIE (analysis, design, development, implementation, and evaluation). 
Pada tahap analysis dilakukan analisis kebutuhan model pembelajaran, analisis kebutuhan berbasis budaya, dan analisis kurikulum diambil dari hasil wawancara. Dari hasil wawancara yang dilakukan tentang model pembelajaran matematika melalui permainan tradisional Jawa belum pernah dilakukan. Namun penyampaian tentang permainan tradisional pernah dilakukan tetapi tidak masuk dalam model pembelajarannya dan belum ada bahan ajar yang memuat permainan tradisional Jawa. Diperoleh informasi bahwa kurikulum yang digunakan saat ini adalah kurikulum 2013 yang dimana dalam kurikulum tersebut siswa dituntut untuk lebih aktif dan dalam proses pembelajarannya diarahkan ke pembelajaran realistik.

Pada tahap design, kegiatan yang dilakukan adalah menetapkan tujuan pembelajaran, merancang skenario atau kegiatan belajar mengajar, merancang perangkat pembelajaran, merancang materi pembelajaran, media pembelajaran dan alat evaluasi hasil belajar. Tahap development merupakan tahapanan membuat produk berupa buku model, buku guru, buku guru, silabus, RPP, dan LKS. Kelengkapan lain yang mendukung model pembelajaran seperti angket respon siswa, lembar keterlaksanaan, lembar kepraktisan, lembar keefektifan dan soal tes juga dikembangkan pada tahap ini.dalam tahap ini juga dilakukan validasi terhadap produk yang dikembangkan oleh beberapa ahli.

Tahap implementation dilakukan pada 19 subjek siswa kelas IV SD N Klegenwonosari. Dalam tahap ini juga dilakukan penilaian oleh observer tentang keterlaksanaan, kepraktisan, dan keefektifan model pembelajaran yang dikembangkan. Hasil observasi ahli menunjukkan bahwa keterlaksanaan model pembelajaran dalam kategori sangat baik dengan skor total rata-rata kegiatan 3,60. Sedangkan kepraktisan model pembelajaran dalam kategori baik dengan skor total rata-rata aspek yang dinilai adalah 3,80. Hasil penilaian terhadap keefektifan juga menunjukkan kategori baik dengan skor total rata-rata aspek 3,80. Pada tahap implementation juga digunakan instrumen catatan lapangan oleh penelitian mengamati dan mencatat aktifitas siswa, komunikasi siswa atau respon siswa yang terjadi selama tahap implementasi. Dalam catatan lapangan menunjukkan siswa antusias dan senang dengan model pembelajaran matematika yang dilaksanakan.

Tahap evaluation pada penelitian ini menggunakan rancangan tes sebagai salah satu indikator untuk mengetahui kelayakan produk pengembangan. Tes evaluasi 
dilakukan pada akhir setelah pembelajaran dengan model pembelajaran yang dikembangkan. Tes evaluasi terdiri dari 10 soal essay singkat yang berkaitan dengan keliling dan luas daerah (persegi, persegi panjang, segitiga). Tes evaluasi ini diberikan kepada 19 subjek siswa kelas IV SD Klegenwonosari. Dari hasil evaluasi, hasil ketuntasan belajar siswa 84,21\% dari KKM 60.

Dalam penelitian ini model pembelajaran dikatakan layak jika memenuhi tiga indicator yaitu kevalidan, kepraktisan, dan keefektifan. Kevalidan produk pengembangan pada penelitian ini diperoleh dari hasil penilaian oleh ahli kemudian dianalisis dan disesuaikan dengan kriteria kevalidan. Penilaian ini dilakukan pada semua produk pengembangan. Dari hasil penilaian ahli terhadap buku model pembelajaran matematika berbasis budaya didapatkan rata-rata skor sebesar 3,79 sehingga model pembelajaran termasuk dalam kategori valid. Dari hasil penilaian tersebut dinyatakan bahwa model pembelajaran matematika berbasis budaya melalui permainan tradisional Jawa valid. Kepraktisan produk pengembangan dilihat dari angket kepraktisan saat model pembelajaran dilaksanakan yang diisi oleh observer. Hasil angket tersebut kemudian dianalisis dan disesuaikan dengan kriteria kepraktisan. Dari hasil penilaian oleh observer didapatkan rata-rata skor 3,80 sehingga tingkat kepraktisan model pembelajaran dalam kategori baik. Model pembelajaran matematika berbasis budaya melalui permainan tradisional Jawa dikatakan praktis jika telah memenuhi kriteria kepraktisan, penelitian yang telah dilakukan sebelumnya oleh Erni \& Riawan (2017), bahwa model pembelajaran dikatakan praktis karena telah memenuhi tingkat kriteria kepraktisan dalam kategori baik dari sebuah model.

Sedangkan keefektifan produk dilihat dari hasil ketuntasan hasil belajar siswa, dan respon siswa bahwa model pembelajaran ini lebih baik daripada yang digunakan sebelumnya. Setelah dilakukan analisis terhadap hasil ulangan, diperoleh hasil yaitu tingkat ketuntasan siswa sebesar $84,21 \%$. Selain itu untuk melihat keefektifan model pembelajaran dilakukan analisis data terhadap respon siswa, diperoleh hasil respon siswa dengan kategori sangat positif dengan presentase 90,90\%. Dilihat dari data tersebut dapat disimpulkan model pembelajaran matematika berbasis budaya efektif digunakaan. Model pembelajaran dikatakan efektif didasarkan kriteria ketuntasan dan hasil belajarnya, sesuai penelitian yang telah dilakukan sebelumnya oleh Erni \& Riawan (2017), bahwa model pembelajaran dikatakan efektif karena telah mencapai indikator 
keefektifan dengan hasil ketuntasan sesuai kriteria minimal dan respon siswa sangat positif.

Pengembangan model pembelajaran sebelumnya dilakukan oleh Mishinta S. A., (2018), bahwa model pembelajaran melalui setting motif batik nusantara dikatakan layak karena telah memenuhi kriteria kevalidan, kepraktisan dan keefektifan.Dapat disimpulkan bahwa model pembelajaran matematika berbasis budaya melalui permainan tradisional Jawa layak digunakan, sehingga dapat dijadikan inovasi dalam pembelajaran matematika.

\section{SIMPULAN DAN SARAN}

Berdasarkan pada hasil penelitian dan pembahasan, maka dapat disimpulkan bahwa: (1) model pembelajaran matematika berbasis budaya melalui permainan tradisional Jawa untuk sekolah dasar adalah valid, (2) model pembelajaran berbasis budaya tersebut memenuhi kriteria praktis dengan kategori baik dengan rata-rata skor 3,79, (3) Model pembelajaran tersebut memenuhi kriteria efektif, selain menganalisis keefektifan dilakukan analisis data terhadap respon siswa, diperoleh hasil respon siswa dengan kategori sangat positif dengan persentase 90,90\%, hasil ketuntasan siswa $84,21 \%$ dan ada peningkatan setelah diterapkan model pembelajaran tersebut. Berdasarkan hal di atas maka model pembelajaran matematika berbasis budaya layak digunakan di sekolah dasar.

Adapun saran untuk penelitian berikutnya adalah: (1) Pengembangan model pembelajaran matematika berbasis budaya perlu dilakukan dengan materi matematika yang lain, agar lebih mempermudah siswa dan guru dalam proses pembelajaran matematika, (2) Budaya yang ada dalam produk pengembangan perlu ditambahkan jadi tidak hanya permainan tradisional Gobag Sodor dan Engklek, tapi permainan tradisional Jawa yang lain agar siswa dapat mengetahui tentang budaya permainan tradisional Jawa lainnya.

\section{DAFTAR PUSTAKA}

Endang, M. 2014. Metode Penelitian Terapan Bidang Pendidikan. Bandung: Alfabeta.

Erni, P. A. \& Riawan, Y. P. 2017. Implementasi Etnomatematika dalam Pembelajaran Matematika di Sekolah Dasar. The 6th University Research Colloqium 2017. 
Diakses dari http://repository.umpwr.ac.id:8080/handle/123456789/91 pada tanggal 30 Oktober 2018.

Erni, P, A. \& Riawan, Y, P. 2017. Integrating Ethnomathematics in Mathematical Learning Design for Elementary School. ICRIEMS Proceedings, ISBN 978-60274529-2-3. Diakses dari http://seminar.uny.ac.id/icriems/proceedings2017 pada tanggal 18 November 2018.

Mishinta S. A. 2018. Pengembangan Model Pembelajaran Matematika dengan Setting Motif Batik Nusantara. Skripsi, tidak diterbitkan. Universitas Muhammadiyah Purworejo.

Sugiyono, 2008. Metode Penelitian Kuantitatif, Kualitatif dan $R \&$ D. Bandung: Alfabeta.

Wicaksono, D, P., Kusmayadi, T, A., \& Usodo, B. 2014. Pengembangan Perangkat Pembelajaran Matematika Berbahasa Inggris Berdasarkan Teori Kecerdasan Majemuk (Multiple Intellegences) pada Materi Balok dan Kubus Untuk Siswa VIII SMP. Jurnal Elektronik Pembelajaran Matematika, Vol. 2, No. 5. Diakses dari http://jurnal.fkip.uns.ac.idpada tanggal 21 Desember 2018. 